\title{
The Effects Of Local Culture On Tourism Products And Domestic Tourist Satisfaction In Tourism Destinations In Gianyar Regency, In The Province of Bali
}

\author{
Ida Bagus Cempena \\ Ida Aju Brahmasari
}

\section{Tatik Suryani}

\begin{abstract}
The beauty of nature, the uniqueness of the culture and the hospitality of its inhabitants put the island of Bali first in the world, beating the Maldives and Phuket, Thailand. Bali ranks first among the 25 best destinations in the world (Trip Adivisor, 2017). The purpose of this study is to prove and analyze the influence of local culture on tourism products and the satisfaction of domestic tourists at tourist destinations in Gianyar regency of Bali province. The population in this study is domestic tourists whose numbers are unknown (unlimited). Convenience sampling was used of 204 respondents. The results of this study prove that local culture has a significant influence on tourism products and the satisfaction of the domestic tourists, as well as the tourism products have a significant effect on the satisfaction of the domestic tourists
\end{abstract}

Keywords: local culture, tourism products, tourist satisfaction.

\section{INTRODUCTION}

Every country in carrying out development efforts does not only rely on one sector of economic activity but also rely on many sectors that are able to encourage economic growth such as agriculture, trade, manufacturing, tourism and others. Indonesia is very potential in tourism sector as it has 13,466 islands with long coastlines as mentioned by the Indonesian Geospatial Information Agency, which is 99,093 km stretching from Sabang to Merauke. In terms of historical and cultural heritage, Indonesia has a diverse culture that is spread across islands with different characteristics and histories. The diversity of local cultures (histories, languages, and tradition) and natural conditions with groups of islands and mountains make Indonesia superior to other countries in the field of tourism.

Tourism becomes a potential element in service industry which is again a trend in the national development of a nation. The number of foreign tourist arrivals in Indonesia in February 2019 increase 6.12 percent (1.27 million visitors) compared to the number of foreign tourist arrivals in February 2018 (1.20 million visitors), and in February 2019 increased by 4.80 percent. In January to February 2019, the number of foreign tourists visiting Indonesia reached 2.48 millions, an increase of 8.19 percent compared to the number of foreign tourists visiting the same period in 2017 (2.30 million visits), commulatively. Occupancy rate for star classification hotel rooms in Indonesia in February 2019 reached an average of 52.44 percent, down 3.77 points compared to the room occupancy rates (ROR) in February 2018 which was recorded at 56.21 percent. Meanwhile, The ROR of star classification hotels in January 2019 compared to the ROR in February 2019 increased by 0.97 points. The average length of stay of foreign and Indonesian guests at star classification hotels during February 2019 was 1.93 days, an increase of 0.01 points compared to the situation in February 2018 (BPS, 2019). Nevertheless, tourism 
experts considered that Indonesian government and stake holders as paying less attention to safety and environmental preservation.

The investment climate that supports tourism is often unsustainable, such as infrastructure which results in high logistics costs, thereby reducing the interest of tourists and investors in the tourism sector. Lack of connectivity both within and between islands in Indonesia with high tourism potential makes it difficult to access and enjoy certain tourist destinations and attractions. At present, Indonesia's tourism sector contributes to approximately $4 \%$ of the total economy. In 2019, the Indonesian government wants to double this figure to $8 \%$ of GDP, a target which implies that in the next 4 years, the number of visitors needs to double to around 20 millions. In order to achieve this target, the Indonesian government focuses on improving Indonesia's infrastructure (including information and communication technology infrastructure), access, health and hygiene as well as increasing online promotion campaigns (marketing) overseas (www.indonesia-investments.com, 2016)

Bali is ranked first of the 25 best destinations in the world. The top 10 best destinations in the world are: 1). Bali (Indonesia); 2). London (UK); 3). Paris (France); 4). Rome (Italy); 5). New York (US); 6). Crete (Greece); 7). Barcelona (Spain); 8). Siem Reap (Cambodia); 9). Prague (Czech Republic); 10). Phuket (Thailand).

2.3 million foreign tourists spent their holiday in Bali by May 2019. This figure increased 2\% compared to the same period in 2018. The number of foreign tourists visiting Bali recorded an increase during January-May 2019. Data recorded in Gusti Ngurah Rai Airport in Bali, there were 2,383,998 million foreign tourists visit the "Island of God", Bali, by air. This number shows a growth in the number of foreign tourists compared to the same period in 2018, which was 40,299 people, or grew by $2 \%$. Here are 10 ranking of foreign tourists coming to Bali based on their home countries (Travel.detik.com.20119) 1) China 519,341 (31\%); 2) Australia 439,412 (26\%); 3) India 151,959 (9\%); 4) United States 103,505 (6\%); 5) United Kingdom 97,157 (6\%); (6) Japan 97,157 (6\%); (7) Malaysia 71,267 (4\%); (8) South Korea 70,821 (4\%); (9) Russia 65,644 (4\%); (10) Germany 62,406 (4\%)

Gianyar Regency is one of nine tourist destination regency in the island of Bali. Gianyar Regency has 390 accommodation places (19 star hotels and 367 non-star hotels). The number of tourist visits to attractions in Gianyar Regency from 2014 to 2018 can be seen from Table 1:

Table 1

Number of Foreign Tourists and Domestic Tourists Who Visited the Regency of Gianyar.

(2014 to 2018)

\begin{tabular}{|c|c|c|c|}
\hline \multirow{2}{*}{ Year } & \multicolumn{2}{|c|}{ Number of Visitors } & \multirow{2}{*}{ Total } \\
\cline { 2 - 3 } & International & Domestic Tourists & \\
\hline 2014 & 1.254 .243 & 667.576 & 1.921 .819 \\
\hline 2015 & 1.278 .628 & 639.603 & 1.917 .691 \\
\hline 2016 & 2.339 .789 & 613.842 & 2.953 .631 \\
\hline 2017 & 3.180 .778 & 661.885 & 3.842 .663 \\
\hline 2018 & 1.267 .692 & 163.513 & 1.431 .205 \\
\hline
\end{tabular}

Sumber: Gianyar Regency Tourism Office (2019)

Table 1 shows that the level of foreign tourist arrivals (tourists) to Gianyar Regency, Bali Province, increased from 2014 to 2017 and decreased in 2018. The number of tourist arrivals 
from 2014 to 2016 declined, although in 2017 the number of domestic tourist arrivals increased, but in 2018 the number decreased again. The level of foreign tourist arrivals (tourists) to Gianyar Regency, Bali Province, increased from 2014 to 2017 and in 2018 decreased. The number of tourist arrivals from 2014 to 2016 decreased, although in 2017 the number of domestic tourist arrivals increased, but in 2018 the number decreased again.

Customer satisfaction is very important for a business as it can create commitment and loyalty to a product. Customers will buy repeatedly, because trust and good service have been created. "Satisfaction is a person's feelings of pleasure or disappointment thatresult from comparing a product or service's perceived performance (or outcome) to expectations" (Kotler and Keller, 2016:153).

The quality of a product depends on the level of customer. A result of the pre-survey research conducted in January to June 2018 for six months with the amount of information of 30 domestic tourists, dominant problem causing factors of dissatisfaction of domestic tourists in tourist destinations in Gianyar regency, Bali province can be seen in the Figure 1:

\section{Figure 1}

The Dominant Problem of Nusantara Tourist Dissatisfaction at Tourist Destinations in Gianyar Regency, Bali Province

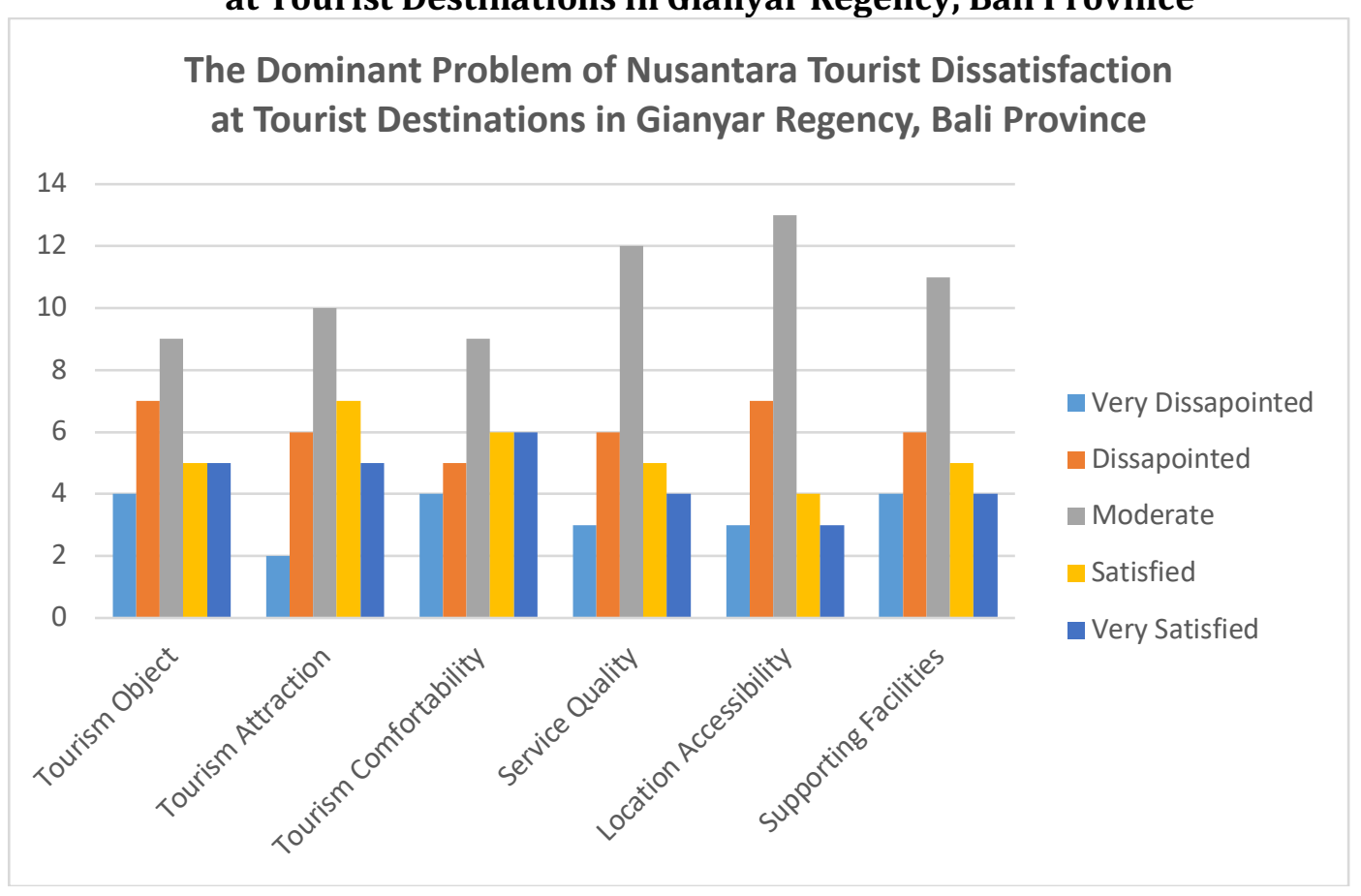

Data on Figure 1 showed main factors causing dissatisfaction of tourists visiting Gianyar regency, the province of Bali are: Tourism object, Tourism attractions, Tourism comfortability, Service quality, Location accessibility, and Supporting facilities provided by tourist or tour guides are not enough to provide perceived value to the satisfaction of domestic tourists. Therefore, every tourism destination in seven sub-districts in Gianyar regency, provide suggestion boxes in order to get feedback from every tourist after visiting a tourism object, in order to improve their service qualities to their customer (visitors).

The strategies carried out are basically aimed at creating customer satisfaction into an absolute measure given by each tourist destination in meeting the needs and desires of every tourist who visits. The level of tourist satisfaction can be measured by the complaints received by the manager from tourists who enjoy the facility. Some factors that influence tourist satisfaction 
are: the tourist attraction itself, the tourist attractions that are presented, the comfort of tourists while in the location, the quality of services obtained by tourists during the location, affordability of the location, supporting facilities available at the location and the environment around the destination.

Kotler and Armstrong (2015:35) define customer satisfaction as: "Customer satisfaction is the extent to which a product's perceived performance matches a buyer's expectations. If the product's performance falls short of expectations the customers is dissatisfied. If performance matches expectations, the customers are satisfied. If performance exceeds expectations, the customers ih highly satisfied or delighted". Customers have high expectations by buying a product that is offered, if that expectation is fulfilled or even exceeds the desires of customers, it will create satisfaction that impacts the desire to make a repeat purchase. Customers are selective in choosing a product, trying to compare one product to another product, or looking for additional information that has a relationship with the product to be purchased, to determine the performance of the product.

Customers can experience one of three general levels of satisfaction: 1 ) if the performance is below expectations, customers will feel disappointed; 2) if the performance is in line with customer expectations will feel satisfied; and 3) if the performance can exceed expectations, the customer will feel very satisfied or happy.

Kotler and Armstrong (2015: 253) define product quality as follows: "Product quality is the characteristics of a product or service that bears on its ability to satisfy stated or implied customer needs". In determining the products to be offered, companies must adjust to customer tastes so that customers feel satisfied. If product quality is improved, then customer behavior can affect customer satisfaction

Based on the background that has been described, the purpose of this study is to examine and analyze the effects of local culture on tourism products and domestic tourist satisfaction in tourism destinations in Gianyar Regency, the province of Bali.

\section{Marketing strategy}

\section{THEORETICAL BACKGROUND}

Marketing strategy is "a marketing logic where the company hopes to create value for customers and can achieve profitable relationships with customers. A marketing strategy is a plan that sets out the company's expectations of the impact of various marketing activities or programs on the demand for its products or product lines in certain target markets" (Kotler and Armstrong, 2012:72). Companies can use two or more marketing programs simultaneously, because each type of program such as advertising, sales promotion, personal selling, customer service, or product development has different effects on demand. Therefore, we need a mechanism that can coordinate marketing programs so that the programs are aligned and integrated synergistically. This mechanism is called a marketing strategy. Generally, the best marketing opportunities are obtained from efforts to expand primary demand, while the best growth opportunities come from efforts to expand selective demand. (Kotler and Armstrong, 2012:193)

\section{Local Culture}

Literally, culture is a way of life that belongs to a group of people which is passed down from one generation to the next. As for the differences between religion, ethnicity, politics, clothing, songs, language, buildings, and works of art that will make the formation of a culture. 
Koentjoroningrat (1974). Local culture can be interpreted as a human and community policy by relying on philosophy, values, ethics, attitudes, procedures and institutional behavior to traditionally manage various natural resources, biological resources, human resources, and cultural resources for the preservation of resources this power for sustainable survival (Brata, 2016). The intrinsic qualities of local culture are 1) the ability to survive in the face of outside cultures, 2) have the ability to accommodate elements of outside culture, 3) able integrated with elements of outside culture into native culture, 4) has the ability to exercise control and give direction to cultural development (Poerpowardojo in Brata, 2016).

Based on the pluralistic nature of Indonesian society, there are 3 cultural groups, each of which has its own style: 1) ethnic/regional culture, 2) local general culture, and 3) national culture. Ethnic culture, means the same as local culture or regional culture, while local general culture depends on the aspect of space, usually on urban space when various local or regional cultures are carried by each newcomer. However, there is a dominant culture that develops, namely the local culture in the city or place, while the national culture is the accumulation of regional culture (Jacobus Ranjabar in Abidin, 2014:167)

\section{Tourism Products}

"A product is anything that can be offered to a market for attention, acquisition, use or consumption that might satisfy a want or need" (Kotler and Armstrong (2015:248). Hunziker and Kraft in Muljadi (2012) revealed that tourism is symptoms that arise from the presence of strangers or the whole relationship of the trip is not for permanent residence and there is no relationship with activities to make a living. So that in carrying out his journey only looking for things in accordance with their wants and needs.

Tourism products are tangible and intangible products, packaged in a single set of trips that can only be enjoyed, if the whole series of trips can provide good experience for people who travel or who use the product. The form of the tourism product is essentially not real, because in a series of trips there are various kinds of elements that are competing to complete, dependence on the type of travel undertaken by tourists. From the description above, it is generally easy to recognize that tourism products consist of accessibility, facilities and services as well as tourist or entertainment attractions

Tourism product is an activity or zone offered to the market to get special attention for visitors. Three important aspects of tourism products: (1) Attraction is the center of the tourism industry. It means that attractions can attract tourists who want to visit them. Usually they are attracted to a location because of certain characteristics. Distinctive features that attract tourists are: a) Natural beauty, b) Climate and weather, and c) Culture. (2). Amenities. It is various supporting facilities for tourists to travel to a tourist destination with its own comfort and satisfaction. These include comfortable accommodation, restaurants, bars, information services, guides, local community attitudes, security and others. (3). Accessibility Associated with all types of transportation, distance or ease of achieving a tourist attraction. As well as other supporting elements (tourism industry players, community and development institutions) that formed a synergistic system in creating motivation for tourist visits. (Bukart and Meddlik in Oka A. Yoeti (2002 :211).

\section{Customer satisfaction}

"Satisfaction is a person's feelings of pleasure or disappointment that results from comparing a product or service's perceived performance (or outcome) to expectations" (Kotler and Keller, 2016:153). "Customer satisfaction is the extent to which a product's perceived performance matches a buyer's expectations". If the product's performance falls short of expectations the 
customers are dissatisfied. If the performance matches are perspective, the customers are satisfied. If performance exceeds expectations, the customers are highly satisfied or delighted (Kotler and Armstrong (2015:35). The satisfaction of domestic tourists is the level of feeling expressed in a happy state or in the opposite condition by domestic tourist visitors in one of the tourist attractions visited.

\section{Conceptual Framework}

The conceptual framework (Figure 2) explained a causal relationship among local culture, tourism Products, and customer satisfaction.

Figure 2

Conceptual Framework

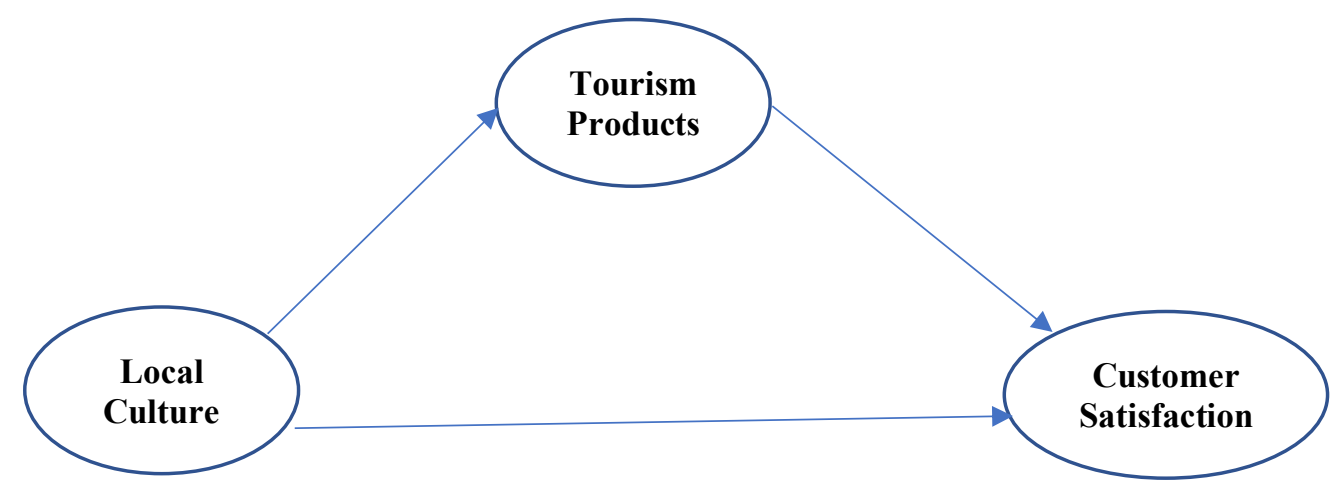

\section{Research Hypothesis:}

\section{Relationship between local culture and tourism products}

The intrinsic qualities of local culture are 1) the ability to survive in the face of outside cultures, 2) have the ability to accommodate elements of outside culture, 3) able integrated with elements of outside culture into native culture, 4) has the ability to exercise control and give direction to cultural development (Poerpowardojo in Brata (2016).

Tourism product is an activity or zone offered to the market to get special attention for visitors. Three important aspects of tourism products: (1) Attraction, is the center of the tourism industry, (2). Amenities. It is various supporting facilities for tourists to travel to a tourist destination with its own comfort and satisfaction. (3). Accessibility, associated with all types of transportation, distance or ease of achieving a tourist attraction. (Bukart and Meddlik in Oka A. Yoeti $(2002: 211)$.

Hipothesis 1: local culture effects tourism products in tourism destination in Gianyar regency, the province of Bali.

\section{Relationship between local culture and customer satisfaction}

The results of this study cannot confirm several theories: According to Koentjoraningrat (1974), the original culture of a group, cultural elements that are universal and are elements that can be obtained in all world cultures, namely: (a) Religious Religion and Ceremonies, (b ) Community systems and organizations, (c) Knowledge systems, (d) Language, (e) Arts, (f) Livelihood systems. According to F.B. Taylor. Culture of a complex whole includes beliefs, decency, art, customs, law, ability and other habits that are often studied by humans as part of society. Theory according to Linton. Culture is the whole attitude and pattern of behavior and knowledge which is a habit that is inherited and owned. 
The results of this study cannot confirm any differences from the following studies:

Kirom, Sudarmiatin, and Adi Putra. (2016), in a study entitled: Certain Factors of Cultural Tourism Attractiveness and Its Effects on Tourist Satisfaction, the results or findings in the Research show that Cultural Factors are the most dominant factors that are considered by tourists and there is a significant positive influence between Culture on Satisfaction Traveler Rui Jin Hoare and Ken Butcher, Griffith (2008), in a study entitled: Whether Chinese Cultural Values Affect Customer Satisfaction or Loyalty, the results or findings in the Research show that from a series of cultural factor regression equations are significantly and positively correlated with customer satisfaction.

Hipothesis 2: Local culture effects tourism products in tourism destinations in Gianyar regency, the province of Bali.

\section{Relationship between tourism products on customer satisfaction}

The results of this study can confirm according to the theory: According to (Poerwanto, 2004). Tourism products are a variety of entities that are inseparable between the quality of the dimensions of one another related to tourist satisfaction. The quality of this tourism product depends on humans. It means that it is humans who create interesting attractions, complete facilities, supporting infrastructure, smooth transportation, and friendly and smiling people. This encourages the satisfaction of tourists who visit.

The results of this study can confirm the similarity of the following studies:

Ibrahim, Malik, Thawil and Sitti Marijam (2019), in a study entitled: Effect of Product Quality and Service Quality on Customer Satisfaction, the results or findings in the Research show that there is a significant influence on Product Quality on Customer Satisfaction.

Linardi, Ricky (2019), in a study entitled: Effect of Product Quality, Service Quality and Price on Customer Satisfaction in RI Watch's Online Shop Business, the results or findings in the Research show that Product Quality partially and Simultaneously has a significant effect on Customer Satisfaction.

Dedek K. Gultom, Paham Ginting, and Beby Kf Sembiring. (2014), in a study entitled: Effect of Service Marketing Mix and Service Quality on Student Satisfaction in Management Study Program, Faculty of Economics, Muhammadiyah University, North Sumatra, the results or findings in the study showed that: Service marketing mix consisting of products influenced the satisfaction of students of Management Study Programs Faculty of Economics, Muhammadiyah University, North Sumatra

Hipothesis 3: Tourism products affect tourist satisfaction in tourism destinations in Gianyar Regency, the province of Bali.

\section{RESEARCH METHOD}

This research is an explanatory research that will explain the causal relationship between variables. The population is domestic tourists whose numbers are unknown (infinit). Respondents were selected using convenience sampling technique. Based on Jacob Cohen's formula:

$$
N=\frac{t}{F^{2}}+U+1
$$

Keterangan:

$\mathrm{N}=$ sampel size)

$f 2=$ Effect Size 
$U=$ The number of changes involved in research

$\mathrm{t}=\mathrm{t}$ table is obtained from $1 \%$ significance table with the number of changes in the study $(U)$.

The value of $t$ table with a significant level of $1 \%$ and $p=0.95$ and $u=5$ is 19.76

$$
N=\frac{19.76}{0.1^{2}}+5+1=203,6
$$

A total sample of 204 domestic tourists as respondents of thie study was determined. Data was analyzed using the Structural Equation Modeling (SEM) method using the statistical program of Analysis Moment of Structure (AMOS), version 22

\section{RESULTS}

The measurement model process is a process of the CFA test that is confirmatory factor analysis. CFA serves to identify whether indicators are constructs of research variables or in other words these indicators are one entity or have undimensionality. CFA test is performed on each variable. Validity test is done through convergent validity, where the indicator is said to meet convergent validity if the indicator has a standardized regression weight $(\lambda /$ factor loading) value $\geq 0.50$

Table 2

Results of Validity and Reliability Testing

\begin{tabular}{|c|c|c|c|c|}
\hline Indikator & $\begin{array}{c}\text { Factor } \\
\text { Loading (FL) }\end{array}$ & $(\mathrm{FL})^{2}$ & Error $\left(1-F^{2}\right)$ & $\begin{array}{l}\text { Construct Reliability } \\
\text { (CR) }\end{array}$ \\
\hline \multicolumn{5}{|c|}{ Local Culture } \\
\hline CL.1 & 0,660 & 0,436 & 0,564 & \multirow{6}{*}{0,838} \\
\hline CL.2 & 0,744 & 0,554 & 0,446 & \\
\hline CL.3 & 0,687 & 0,472 & 0,528 & \\
\hline CL.4 & 0,675 & 0,456 & 0,544 & \\
\hline CL. 5 & 0,663 & 0,440 & 0,560 & \\
\hline CL.6 & 0,649 & 0,421 & 0,579 & \\
\hline \multicolumn{5}{|c|}{ Tourism Products } \\
\hline TP.1 & 0,636 & 0,404 & 0,596 & \multirow{10}{*}{0,892} \\
\hline TP.2 & 0,597 & 0,356 & 0,644 & \\
\hline TP.3 & 0,720 & 0,518 & 0,482 & \\
\hline TP.4 & 0,668 & 0,446 & 0,554 & \\
\hline TP.5 & 0,675 & 0,456 & 0,544 & \\
\hline TP.6 & 0,695 & 0,483 & 0,517 & \\
\hline TP.7 & 0,731 & 0,534 & 0,466 & \\
\hline TP.8 & 0,765 & 0,585 & 0,415 & \\
\hline TP.9 & 0,637 & 0,406 & 0,594 & \\
\hline TP.10 & 0,586 & 0,343 & 0,657 & \\
\hline \multicolumn{5}{|c|}{ Customer Satisfaction } \\
\hline CS.5 & 0,661 & 0,437 & 0,563 & \multirow{5}{*}{0,838} \\
\hline CS. 4 & 0,689 & 0,475 & 0,525 & \\
\hline CS.3 & 0,693 & 0,480 & 0,520 & \\
\hline CS.2 & 0,730 & 0,533 & 0,467 & \\
\hline CS.1 & 0,792 & 0,627 & 0,373 & \\
\hline
\end{tabular}

Source: Primary Data Processed (2019) 
Table 2 shows that all the indicators on the construct of the research variable have a loading factor value greater than 0.50 . Therefore, the indicators are valid and can be used to construct the model.

\section{Hypothesis Testing}

The next step is to test the hypothesis using the CR value and its probability. The parameter of the presence or absence of partial effect can be determined based on the value of CR (Critical Ratio). To determine whether there is an influence of exogenous variables on endogenous variables and endogenous variables on endogenous variables, the provisions are used if the calculated $C R$ value $\geq 1.96$ or a significance value $\leq 0.05$, then it is decided that there is a significant influence between these variables.

Following are the results of hypothesis testing based on the value of standardized regression weight in the structural equation model after modification. You can see the following table 3:

Table 3

Result of Hypothesis Testing

\begin{tabular}{|c|c|c|c|c|c|c|c|}
\hline Hipothesis & \multicolumn{3}{|c|}{ Causality } & Koef. & C.R. & P-value & Note \\
\hline $\mathrm{H}_{1}$ & $\begin{array}{l}\text { Local } \\
\text { Culture }\end{array}$ & & $\begin{array}{l}\text { Tourism } \\
\text { Products }\end{array}$ & 0.271 & 3.557 & 0.000 & Significant \\
\hline $\mathrm{H}_{2}$ & $\begin{array}{l}\text { Local } \\
\text { Culture }\end{array}$ & $\rightarrow$ & $\begin{array}{l}\text { Customer } \\
\text { Satisfaction }\end{array}$ & -0.239 & 4.285 & 0.000 & Significant \\
\hline H3 & $\begin{array}{l}\text { Tourism } \\
\text { Products }\end{array}$ & . & $\begin{array}{l}\text { Customer } \\
\text { Satisfaction }\end{array}$ & 0.333 & 3.276 & 0.001 & Significant \\
\hline
\end{tabular}

Sumber: Primary data analyzed using Amos 22 (2019)

\section{DISCUSSION}

The result of hypothesis testing proved that the local culture has positive and significant effect on tourism products as evidenced from the CR value of 3.557 (greater than 1.96) and the significance level ( $p$-value) of 0,000 (less than $5 \%$ ). The coefficient of regression weight is only 0.271 . This means that the higher the local culture will have a real impact on improving tourism products. Thus, the hypothesis that local culture has a significant effect on tourism products in tourist destinations in the district of Gianyar, Bali province, was accepted.

can enjoy local culture, such as burial for the deceased The results of hypothesis testing proved that local culture has significant, but negative effect on costumer (domestic tourist) satisfaction, as evidenced by the CR value of 4.285 (greater than 1.96) and the significance level (p-value) of 0,000 (less than 5\%). The coefficient of regression weight is -0.239 . This means that the higher the local culture, the lower the customer (domestic tourist) satisfaction on tourist destinations in the district of Gianyar, Bali province. Thus, the hypothesis stating that local culture has a significant effect on costumer (domestic tourist) satisfaction on tourist destinations in the district of Gianyar, Bali province, was accepted. However, the negative effect may be due to restrictions for any domestic tourist, for examples: 1) Only those domestic tourists who are Hindu can enjoy a certain local rituals (Balinese or Hindu tradition); 2). Only those domestic tourists who have long holiday complete tradisional ceremony, may takes more than a week because considering the good day determined by the priest and besides preparing the completeness of the spiritual implementation of the ngaben ceremony or death ceremony.

The result of hypothesis testing proved that tourism products has positive and significant effect on customer (domestis tourist) satisfaction, as evidenced by the CR value of 3.276 (greater than 1.96) and the significance level (p-value) of 0.001 (smaller than 5\%). The coefficient of regressio weight is 0.333 . This means that the higher the quality of tourism 
product will have a real impact on increasing the customer (domestic tourist) satisfaction. Thus, the hypothesis stating that tourism products have a significant effect on the satisfaction of customer (domestic tourist) on tourist destinations in Gianyar regency, Bali province, was accepted

\section{CONCLUSION}

Local culture have a positive and significant effect on tourism products in tourist destinations, in Gianyar regency, Bali province. The result of this study confirmed a theory stated by Poerpowardojo in Brata (2016), that the intrinsic qualities of local culture are 1) the ability to survive in the face of outside cultures, 2) have the ability to accommodate elements of outside culture, 3) able integrated with elements of outside culture into native culture, 4) has the ability to exercise control and give direction to cultural development. The result also confirmed a theory stated by .(Bukart and Meddlik in Oka A. Yoeti (2002 :211)., tourism product is an activity or zone offered to the market to get special attention for visitors. Three important aspects of tourism products: (1) Attraction is the center of the tourism industry, (2) Amenities. It is various supporting facilities for tourists to travel to a tourist destination with its own comfort and satisfaction, and (3) Accessibility associated with all types of transportation, distance or ease of achieving a tourist attraction.

2) Local culture have a significant, but negative effect on customer (domestic tourist) satisfaction in tourist destinations, in Gianyar regency, Bali province.

The results of this study cannot confirm a theory stated by Koentjoraningrat (1974), that the original culture of a group, consists of cultural elements that are universal and are elements that can be obtained in all world cultures, namely: (a) Religious Religion and Ceremonies, (b) Community systems and organizations, (c) Knowledge systems, (d) Language, (e) Arts, (f) Livelihood systems. Result of this study confirmed a theory stated by Taylor, F. B. That culture as a complex whole includes beliefs, decency, art, customs, law, ability and other habits that are often studied by humans as part of society. Result of this study also confirmed a theory stated by Kotler and Keller (2016:153) that satisfaction is a person's feelings of pleasure or disappointment that results from comparing a product or service's perceived performance (or outcome) to expectations" and Kotler and Armstrong (2015:35), that customer satisfaction is the extent to which a product's perceived performance matches a buyer's expectations. The satisfaction of domestic tourists is the level of feeling expressed in a happy state or in the opposite condition by domestic tourist visitors in one of the tourist attractions visited.

The result of this study cannot confirm any similarities from a number of studies conducted by Kirom, Sudarmiatin, and Putra. (2016), as well as Hoare, Butcher, and Griffith (2008) whose studies proved that a series of cultural factors are positively and significantly correlated with customer satisfaction.

3) Tourism products have positive and significant effect on customer (domestic tourist) satisfaction in Gianyar regency, Bali province.

The result of this study can confirm a theory that is stated by Poerwanto (2004) that tourism products are a variety of entities that are inseparable between the qualities of the dimensions of one another related to tourist satisfaction. The quality of this tourism product depends on humans. It means that it is humans who create interesting attractions, complete facilities, supporting infrastructure, smooth transportation, and friendly and smiling people. This encourages the satisfaction of tourists who make a visit. 
The results of this study can confirm the similarity of a number of studies conducted by Ibrahim, Malik, Thawil and Marijam (2019), as well as Linardi and Ricky (2019) whose studies proved that there are a significant effects of product quality on customer satisfaction.

\section{References}

A.J, Mulyadi.2012. Kepariwisataan dan Perjalanan. Jakarta: Raja Grafindo Persada.

Abidin, Yusuf Zainal. dan Beni Ahmad Saebani. 2014. Pengantar Sistem Sosial Budaya di Indonesia. Bandung: Pustaka Setia.

Armstrong, Kotler. 2015. Marketing an Introduction. 12 ${ }^{\text {th }}$ edition. Prentice Hall. England: Pearson Education, Inc. Assauri, Sofjan. 2013. Manajemen Pemasaran. Jakarta: Rajawali Pers.

Koentjaraningrat - 2000 Kebudayaan Mentalitas dan Pembangunan

Koentjaraningrat Dian Rakjat, 1967 - 278 halaman Beberapa pokok antropologi social

Kotler, Philip and Kevin Lane Keller. 2016. Marketing Management, $15^{\text {th }}$ edition. New Jersey: Pearson Pretice Hall, Inc.

Oka A. Yoeti (1997:2) "Perencanaan dan Pengembangan Pariwisata” 